\title{
Transformacija političkog pojma tranzicije u povijesnom lomu 1989./1991. u Hrvatskoj
}

\author{
DOI: $10.5613 /$ rzs.51.1.0331 \\ UDK 321.74-043(497.5)"1989/1991" \\ 33.025.28(497.5)"1989/1991" \\ 330.111.6(497.5)"1989/1991" \\ 330.5-043.72(497.5)"1989/1991" \\ Pregledni rad \\ Primljeno: 23. 4. 2020. \\ Objavljeno elektronički: 31. 3. 2021.
}

Dimitrije BIRAČ (D) https://orcid.org/0000-0002-3226-9843

Fakultet političkih znanosti Sveučilišta u Zagrebu, Hrvatska

dimitrije.birac@gmail.com

\section{SAŽETAK}

Rad je pokušaj doprinosa istraživanjima transformacije političkih pojmova na primjeru pojma tranzicije. Razdoblje unutar kojeg se istražuje ovaj politički pojam odnosi se na tzv. povijesni lom 1989./1991. u tadašnjoj Socijalističkoj Republici Hrvatskoj, odnosno Republici Hrvatskoj. Postavljanjem metodološkog okvira na temelju koncepcija Michaela Freedena i Reinharta Kosellecka, u radu se pokušava odgovoriti na pitanja kako se odvijala transformacija političko-ekonomskog pojma tranzicije, koji su njegovi konstitutivni elementi, u kakvu su međusobnom odnosu te na koji su način izražavali tadašnju stvarnost. Osnova rada su analize tjednika Danas i mjesečnika Banka, uz različite druge znanstvene članke, intervjue i knjige. Pokazalo se da su tadašnji akteri svojim djelovanjem u pravcu razvoja političkog pojma tranzicije, kao krajnji rezultat pridonijeli kontekstu obnavljanja kapitalizma. Pritom su tadašnju stvarnost dijelili na dvije glavne sfere, na političku i ekonomsku, te su vlastite perspektive smještali unutar svake od spomenutih sfera. Njihove težnje u političkoj sferi bile su demokratizacija i pluralizam političkih stranaka, a njihove težnje u ekonomskoj sferi privatno vlasništvo i povećanje efikasnosti. Posljedica tog djelovanja jest formuliranje tadašnjih korjenitih promjena (povijesnog loma) kroz politički pojam tranzicije koji danas uvelike određuje našu koncepciju o nedavnoj prošlosti.

Ključne riječi: politička tranzicija, ekonomska tranzicija, kapitalizam, Hrvatska 


\section{UVOD}

Posljednjih godina u domaćim znanstvenim časopisima političko-ekonomske tematike sve se manje istražuje proces tranzicije. Umjesto toga, neki drugi politički i ekonomski procesi i pojave postale su dominantne, pa i probitačne teme za analizu. No, treba primijetiti da se 2020. godine navršilo točno trideset godina od prvih višestranačkih parlamentarnih izbora u tadašnjoj SR Hrvatskoj i od formalnog početka tranzicije u Hrvatskoj. Zašto se onda danas, kad postoje objektivni razlozi zbog kojih se protekli period može proučavati sine ira et studio, sve manje istražuje taj proces? Pritom je dobro poznato da on uključuje notorni proces pretvorbe i privatizacije? ${ }^{1}$ Bez pretvorbe i privatizacije ne bi bilo tranzicije u njezinu punom smislu, što znači da su ovi procesi temelji današnjega hrvatskog socioekonomskog sistema. To danas nije toliko očito budući da se povijesni lom 1989./1991. percipira gotovo isključivo kroz političku sferu u užem smislu i njezina sastavnog elementa, borbe za republičku (nacionalnu) samostalnost u odnosu na tadašnju jugoslavensku federaciju. Također, istraživanja ne ulaze toliko detaljno u holističku analizu samoga tranzicijskog procesa. Kao da se ne sagledava stvarni razvoj tranzicijskog procesa, koji za osnovnu pretpostavku ipak nema umjetno stvorenu razdiobu na politički i ekonomski dio. Jedno od mogućih ograničenja svakako je bilo to što je većina radova pisana kad je za njih postojao politički i intelektualni interes, to jest u prvih petnaest do dvadeset godina. To u karijernom smislu može biti isplativo, ali nam u znanstvenom smislu neki odgovori postaju jasnijima tek protekom vremena. Stoga je uočljiv svojevrstan paradoks - sad kad se tranzicija može efikasnije proučavati, za to je sve manje zanimanja.

Ovaj rad pokušava djelomično ispraviti postojeće stanje, tako što istraživanju tranzicijskog procesa pristupa preko analize transformacije tranzicije kao političkog pojma. Tim pristupom, dakle uvidom u transformaciju sadržaja utisnutog u pojam tranzicije koji se s obzirom na društveni kontekst mijenjao, a bio izražavan kroz utjecaj političkih aktera i jezik medija, rad teži pridonijeti sveobuhvatnijoj analizi tog utemeljiteljskog procesa današnje Hrvatske. Fokus nije toliko na svakodnevnim povijesnim događajima i njihovu utjecaju na političke i ekonomske procese, koliko na dinamici unutar same ideološke sfere koja se manifestira u političkim pojmovima kao njezinim konstitutivnim elementima.

Ipak, ističemo da je glavno ograničenje ovog članka to što ne obrađuje vezu pojedinih tipova diskursa o tranziciji s konkretnim društvenim akterima. Pojam se

1 Drugim riječima, proces pretvaranja društvenog u državno vlasništvo koje se onda putem privatizacije prodaje privatnom vlasniku, a sve zbog toga, kako se govorilo tada, da se ustanovi poznati titular vlasništva. Ovo je bilo kompatibilno navođenju da je društveno vlasništvo neefikasno iz razloga što je svačije i ničije. 
političkih aktera i elita spominje samo rubno, stoga nedovoljno da bi se detektiralo tko su bili zagovornici a tko oponenti tranzicijskih promjena u razmatranom razdoblju. Zato se na nekim mjestima može dobiti dojam da je "tranzicija" nedovoljno konkretizirana i da se pojavila sama od sebe. lako obrađujemo poglede novinara i ekonomista, koji su svojom pisanom riječi uvelike oblikovali sadržaj pojma tranzicije, ipak je politička sfera tom sadržaju omogućila ideološku transformaciju. Stoga je potrebna i analiza odnosa političkih aktera prema tranziciji, koja će svakako biti obrađena u nekom budućem članku.

Rad se sastoji od dvaju glavnih dijelova i zaključka. U prvom se dijelu postavlja i pojašnjava metodološki okvir. Ključne su odrednice tog dijela da povijest nije spoznatljiva kao cjelina, ali da se njezinu proučavanju najviše možemo približiti pretpostavimo li ju najprije kao cjelinu, umjesto kao skup različitih nepovezanih dijelova. Zatim da trebamo osvijestiti da je za istraživanje nekog perioda u povijesti bitno proučiti pojmove koji su u tom periodu bili aktualni i dominantni te načine na koji su različiti procesi formulirani i, konačno, da je naš predmet istraživanja povijesni lom 1989./1991., odnosno period prijelaza iz sistema koji više nije ("samoupravni socijalizam") u sistem koji još nije ("kapitalizam”). Drugi dio rada razrađuje temu istaknutu u naslovu, transformaciju pojma tranzicije. Radi efikasnije razrade, ovaj je dio podijeljen na dva dijela - političku tranziciju i ekonomsku tranziciju. Dok se $u$ istraživanju pojma političke tranzicije bavimo autorima koji su pisali o važnim sastavnim elementima, $u$ istraživanju pojma ekonomske tranzicije analizirali smo dva pisana medija - tjednik Danas i mjesečnik Banka. U zaključku slijedi sažeta rekapitulacija istraživačkih rezultata.

\section{METODOLOŠKI OKVIR}

Razrada metodološkog okvira kreće se na trima osnovnim razinama: u osvještavanju da se analiza povijesnog loma može realizirati i kroz analizu transformacije političkih pojmova; u detektiranju što je to uopće politički pojam i o kojem političkom pojmu, ili više njih, govorimo u kontekstu povijesnog loma 1989./1991.; u samoj analizi transformacije konkretnoga političkog pojma.

Započinjemo tvrdnjom da se "totalitet povijesti društva nikad ne može predstaviti totalitetom jezika" (Koselleck, 1989: 311). Ili, povijest se ne može spoznati u totalitetu (Jameson, 1981). ${ }^{2}$ Ta tvrdnja ima daljnje konzekvencije. Prvo, pokazuje nam da postoji bitna razlika između "spontanog odvijanja redoslijeda događaja" i priče (interpretacije) o njemu (Koselleck, 1989: 312). Nužno je imati na umu pret-

Zato Jacques Lacan piše: "Ne govorim cijelu istinu jer nema načina da kažem sve. Reći sve doslovno je nemoguće: nedostaje riječi” (v. Lacan, Hollier, Krauss i Michelson, 1987: 7). 
postavku da se interpretacija događaja ne podudara s tim događajem ili slijedom događaja u potpunosti te da interpretatori djeluju unutar političkog konteksta pa su njihove interpretacije, u krajnjoj liniji, njime uvjetovane. ${ }^{3}$ To znači da istraživač treba razlikovati kakvu povijesnu funkciju pojmovi imaju, od njihova korištenja za kojekakve interese, pa su u tom smislu suprotstavljeni "duh vremena" i onaj izbor vodećih pojmova koji svojim izborom postaju "signatura idejnopolitičkog opredeljenja njihovih korisnika” (Kuljić, 2018: 27). Drugo, navedena Koselleckova tvrdnja ukazuje nam na objektivnu nužnost razvoja i egzistencije političkih pojmova, imamo li na umu, jasno, da govorimo o društvenom odnosno političkom lomu kad govorimo o povijesnom lomu, a ne o lomu (engl. rupture) uopće.

Što su to politički pojmovi? To su jedinice analize političkog mišljenja, ali to su i konstitutivni elementi teorija. Njihovi "vanjski oblici” jesu riječi, a odnos teorije prema pojmu usporediv je s odnosom jezika prema riječi (Freeden, 2006: 48). Teorija (jezik) jest njihov organizator, regulator, skup pravila. No, konkretnim organiziranjem političkih pojmova na poseban način, njihovom kontekstualnom (dakle, praktičnom) konfiguracijom nastaju ideologije (Freeden, 2006). Ali to znači da i nema idealnih ideologija, koje čine savršeno zamišljeni politički pojmovi. Inače bi pojam kao sama riječ - imao intrinzično značenje (Freeden, 2006). Stoga se i analiza političkih pojmova provodi tako da se oni lociraju onakvi kakvi se zaista pojavljuju, umjesto da ih se apstraktno sagledava, bez dodira sa stvarnošću (Freeden, 2006). Da bismo razradili taj metodološki okvir, napomenimo da politički pojmovi, kroz interakciju s drugim političkim pojmovima, postaju vrlo konkretnima, ispunjenima. To nam je važno jer daljnja razrada okvira ide dvostrukim smjerom. Stoga se ovdje zadržavamo na tzv. nadgradnji (Marx) i na tome kako unutar nje politički pojam razvija svoj utjecaj. ${ }^{4}$

Prvo, omogućuje nam da historijski proces prerađen pojmovno, pa onda i transformaciju pojma, istražimo koristeći se kategorijama "kontinuiteta" i "loma". Budući da na političkom i društvenom nivou (a taj upravo promatramo) ima različitih oblika kontinuiteta i različitih oblika lomova, "najteža je zadaća uspostaviti adekvatan odnos između svih tih različitih oblika i razina lomova" (Koselleck, 2006: 100). ${ }^{5}$ Već je dosta učinjeno time što je problem osviješten. Osim toga, treba pret-

3 "Čovek je biće nadareno jezikom i živi u grupi koja ima vlastite interese. Obe činjenice određuju njegov odnos prema prošlosti: prošlost se definiše semantičkim kategorijama i tumači u skladu s grupnim interesima" (Kuljić, 2018: 29).

4 Čini nam se da je Francis Fukuyama s pravom napao "ekonomski materijalizam" kad je pisao da se: "niti jedna respektabilna suvremena teorija ekonomskog razvoja ne bavi ozbiljno sviješću i kulturom kao matricom unutar koje se formira ekonomsko ponašanje. Neuspjeh da se spozna kako korijeni ekonomskog ponašanja leže u oblasti svijesti i kulture vodi uobičajenoj pogrešci pripisivanja materijalnih uzroka fenomenima koji su idealne prirode" (Fukuyama, 1989: 7).

5 Dok na primjer Josip Županov smatra dobrim što u pogledu analitičkog pristupa čini "kopernikanski 
postaviti neravnomjernost procesa kao i njegov prijelazni karakter. Dakle, pretpostaviti da se u razdoblju povijesnih lomova isprepleću (sukobljavaju, nadopunjuju, poništavaju) tendencije nestajućeg i nastajućeg. Analizirajući Koselleckove poglede, Kuljić tako piše da je za njega značajna kategorija "istovremenosti neistovremenog" koja označava slojeve vremena uopće, tj. "u vremenskom pogledu snage različitih izvora čije se oprečne logike i dinamike prožimaju unutar zajedničke strukture. Reč je o neharmoničnom sapostojanju društvenih procesa različite starosti koji se označavaju sa: već, još ne i još uvek... To je osnovno iskustvo svih istorija" (Kuljić, 2018: 36). ${ }^{6}$

Drugo, omogućuje nam da se uhvatimo ukoštac s problemom (ne)razlikovanja “'pravih' ideoloških tvrdnji od prikrivenih retoričkih vježbi”. Uistinu, postoji jaz između onoga što se retorikom nameće kao dominantna matrica te ideologije koja je u njezinoj pozadini. To je zato što se retorika nerijetko pojednostavljuje pa ideologija gubi na kompleksnosti. Freeden nudi četiri odgovora na taj problem: najprije je potrebno provesti kontekstualnu analizu, zatim osvijestiti da ideologije nisu samo proizvedene, nego i konzumirane, što govori o tome da su najefikasnije one ideologije koje javnost najmanje uočava, onda je bitno analizirati samu retoriku radi uočavanja specifičnih interpretacija političkih pojmova te, konačno, "dekodirati na podsvjesnoj razini" onu retoriku koja je neiskrena, čiji akteri ne mogu ili ne žele anticipirati posljedice djelovanja ideologije kojoj inkliniraju (Freeden, 2006: 35, 36).

Osim toga, politički pojmovi koji se razvijaju, govorimo li o povijesnim lomovima, usporedno s razvojem različitog socioekonomskog sistema, dobivaju svoje značenje putem borbe s onim pojmovima socioekonomskog sistema koji nestaje. Uspješnost te borbe ne ovisi toliko o samom pojmu (pojam nema intrinzično značenje), koliko o akterima koji ga pune sadržajem i o samom sadržaju. Tada se pojavljuje "napetost između svjesnog i nesvjesnog" kao centralni aspekt u analizi ideologija" (Freeden, 2006: 21). ${ }^{7}$

Prema tome, istraživanje u ovom radu pokušat će što više slijediti postavljeni metodološki okvir, kojem bi još trebalo dodati i dvije metodološke napomene. Budući da se u radu analizira kontekst povijesnog loma 1989./1991., najvažnije je imati na umu moment prijelaza. ${ }^{8}$ To znači da stalno treba uzimati u obzir ideologije dvaju sistema ("samoupravnog socijalizma" ili onog koji nestaje i "kapitalizma" ili onog koji nastaje) i odnose njihovih glavnih političkih pojmova, kako antagonističke

obrat u svojoj analizi: u tadašnjem ( $a$ i u današnjem) društvu problem je upravo u kontinuitetu, koji seže duboko u tradicionalno društvo" (Županov, 1995: 9, kurziv autorov).

$6 \quad$ U istoj knjizi Kuljić prikazuje i kritički obrađuje Kosseleckovu misao na str. 33-61.

7 U cijelom procesu opisivanja i analize određenog diskursa, određenih političkih pojmova i ideologije ovdje egzistira i političko nesvjesno (Jameson, 1981).

$8 \quad$ Prijelaz ovdje ne isključuje diskontinuitet jer ga gledamo i u širem smislu. 
tako i komplementarne. To također znači da istraživač mora osvijestiti da u tim prijelaznim momentima društvena dinamika probija na površinu, ponajviše iz razloga što se tu odvijaju "trenuci 'zgušnjavanja povijesti”" (Puhovski, 1990: 98). Stoga je posve moguće da nešto što vrijedi, primjerice, u siječnju 1989. te se tumači na jedan način, može u rujnu iste godine ili u svibnju iduće označavati nešto posve drugo. Tako Milić piše u drugoj polovini 1989.: "Partija može biti sigurna da u nas još nije stvorena realna socijalna snaga koja može tako lako preuzeti vlast..." (Milić, 1989: 60). Za manje od godinu dana, ta je partija doživjela historijski politički poraz. ${ }^{9}$ Ta duboko pogrešna politička procjena uzrokovana je upravo time što autor nije bio svjestan revolucionarnog karaktera perioda u kojem je djelovao, odnosno nije osvijestio da društvene tendencije počinju ubrzavati. Mutatis mutandis, ukoliko istraživač ne polazi od pretpostavke stalnih mijena i gotovo svakodnevnih prijelaza jednoga u drugi oblik - riskira da mu stvarnost koju izučava izmakne pred očima.

Konačno, druga napomena tiče se analize ekonomske tranzicije kroz faze tzv. sadržajne transformacije, kao i analize medijskog sadržaja tjedna Danas i mjesečnika Banka. Budući da se te analize nalaze kasnije u tekstu, naknadno ćemo dati njihovu metodološku pozadinu.

\section{TRANSFORMACIJA POJMA TRANZICIJE}

Ključni pojam koji izdvajamo jest tranzicija. Pojam se veže uz Huntingtonovu tezu o "trećem valu demokratizacije", koji se odvijao sedamdesetih, osamdesetih i devedesetih godina 20. stoljeća. Prvi dugi val demokratizacije, prema Huntingtonu, započeo je u SAD-u 1820-ih, a trajao je jedno stoljeće. Drugi val je započeo neposredno nakon Drugoga svjetskog rata (Huntington, 1991). Za treći su val važna dva faktora: "učinak snježne grude" koji u okviru vala demokratizacija može presudno utjecati na potencijalno tranzicijsku zemlju da krene smjerom demokratizacije, i "zona političke tranzicije" kao okolnost zemlje što je srednje razvijena jer tada ima najveće izglede za tranziciju prema demokraciji (Huntington, 1991: 16, 31). Da se pojam tranzicije najuže veže uz demokraciju, možemo vidjeti i iz poznate pretpostavke tranzicijske teorije da se kretanje zemlje od diktature, može promatrati kao njezina "tranzicija prema demokraciji" (Carothers, 2002: 6).

Dakle, kad se analizira tranzicija, onda se zapravo analizira politička (demokratska) tranzicija. Neki autori tim pojmom označavaju prijelaz iz totalitarnog u demokratsko društvo i govore o procesu demokratske konsolidacije (Ilišin, 1998). Naglašavajući presudnu dinamiku "političke strukture" i "političke kulture", politolog

9 Sličnu prognozu daje i Dimitar Mirčev, Suradnik centra 'Edvard Kardelj' u Ljubljani: "Bojazan od (građanske, op. autora) restitucije je... potpuno neopravdana, pogotovo u uslovima predominacije društveno-svojinskih odnosa" (Mirčev, 1989: 71). 
Pero Maldini piše o tranziciji kao razdoblju ispunjenom transformacijskim procesima, "između propasti starog sustava i učvršćenja novoga, demokratskog sustava". Vrlo bitna opaska ovog autora jest da su u tranziciji pravila političke igre nestalna. To nas ponovno vodi prema konceptu demokratske konsolidacije ili konsolidacije "demokratskog sustava" (Maldini, 2006: 89, 91). ${ }^{10}$ Drugim riječima, Maldini, Ilišin, Kasapović i Lalić, koristeći se pojmom demokratske konsolidacije, na domaćem tržištu ideja uspostavljaju tendenciju koju je Raj Kollmorgen prozvao "konsolidologijom" (Kollmorgen, 2013: 90). To je možda moglo imati za posljedicu da se previdi tendencija da se paradigma tranzicije pokušava primijeniti na one zemlje čiji politički razvoj tu istu paradigmu dovodi u pitanje (Carothers, 2002). Pa se sve više govori o konsolidaciji, to jest nužnosti neke zemlje da ostvari konsolidaciju. lako, treba reći da Maldini i Lalić ovu opasnost ne samo prepoznaju, nego ju i analiziraju (Lalić, Maldini i Andrijašević, 2010: 38-41). Općenito, u zajedničkom članku oni tvrde da teorija tranzicije nije prikladna budući da se zasniva na Huntingtonovoj tezi o trećem valu demokratizacije, koja stavlja znak jednakosti između procesa u Južnoj Americi i Istočnoj Europi. Na tom tragu uvode novu koncepciju "četvrtog vala” prema Michaelu McFaulu (Lalić, Maldini i Andrijašević, 2010: 37). Također, autori smatraju i da pristup političke tranzicije nije dovoljan jer ne obuhvaća svu kompleksnost procesa (Lalić, Maldini i Andrijašević, 2010: 32, 33, 35).

Poželjno je razlučiti tranziciju od transformacije. Tranzicija jednostavno označava određeni interval promjena od jednog režima prema drugom (Cifrić, 1996). S druge strane, ako tranziciju postavimo kao poželjan cilj, dakle "normativno", onda društvene promjene koje vode tom cilju mogu se nazvati "transformacije" konkretnih društvenih struktura (Cifrić, 1996: 137). Za razliku od normi, transformacija se odnosi na promjenu realnosti, bila ona institucionalna, industrijska i gospodarska struktura. Dalje, Marius Søberg navodi Guillerma O’Donella, jednog od ključnih autora tranzicijske teorije, koji piše o dvjema tranzicijama: "prvoj koja vodi prema uspostavi demokratske vlade i drugoj koja vodi konsolidaciji demokracije" (Søberg, 2007: 32). Hrvatski slučaj tranzicije definira istodobne procese demokratizacije, uspostave države i izbijanje rata. $U$ tom kontekstu isti autor tranziciju u Hrvatskoj promatra kroz tri faze, različito od Kasapović (Søberg, 2007: 32, 33 i 40). Inicijalna faza (1989. - 1995.) koja uključuje dolazak HDZ-a na vlast, borbu za izgradnju države, nezavisnost i rat. Druga faza (1995. - 1999.), odnosno od Dejtonskog sporazuma i završetka rata pa do smrti Franje Tuđmana i treća faza koja počinje vladom Ivice Račana. Vjeran Katunarić je pak obrnuo narativ kad tvrdi da hrvatsko društvo ne kreće od nule, nego da je stara struktura doživjela političku nadgradnju (Katunarić, 1995).

10 Maldini još govori o "oblicima tranzicije", odnosno o načinima njezine izvedbe. Strategija te provedbe ovisi o kulturi određenog društva (Maldini, 2006: 92). 
Nakon kraćeg pregleda, ustvrdimo da za naš slučaj pojam tranzicija u sebi uključuje dvije osnovne inačice - političku tranziciju i ekonomsku tranziciju. Podjela je analitička u prvom redu. Odnosi među pojmovima su od velike važnosti jer nam ukazuju na cjelinu kao uzajamni sklop "povezanih misaonih kategorija“ (Kuljić, 2018: 16). Pritom je potrebno uočiti "da vodeći historijski pojmovi bolje rekonstruišu onaj prilično neuhvatljivi, ali vrlo značajni odnos između konkretnih iskustava i očekivanja jednog doba, odnosno da su bolja signatura hegemonog smisla jedne istorijske epohe nego što su to suve arhivske činjenice (zapisane odluke i izveštaji)" (Kuljić, 2018: 65). Upravo je takav i pojam tranzicije.

Koje su po nama možda i dvije glavne osobine tranzicije? Ponajprije, tranzicija je dovoljno apstraktan pojam da može biti upotrebljiv - može označavati sve i ništa. On se zbog te svoje apstraktnosti "obraća ljudima iz raznih slojeva i raznih prostora s često dijametralno suprotnim iskustvima" (Kuljić, 2018: 45). Tako o tranziciji tih godina govori radnik u samoupravnom poduzeću, novinar u svojoj kolumni ili reportaži, političar u svom govoru i obrtnik u svojoj kritici nacionalne i savezne vlasti. Pritom tranzicija za svakoga od njih ima različito značenje, kao što će im, jednom kad se u taj pojam utisne sadržaj pobjedničke političke opcije, isti taj pojam tranzicije mistificirati njima neposrednu realnost. ${ }^{11}$ Mistifikacija se ponajviše očituje u drugoj osobini - da je taj pojam jedan od onih koji "nagovještava budućnost”. To znači da se taj "pojam ne kreće, nego pokreće” (Kuljić, 2018: 55). Praktično, u našem slučaju to znači da su spomenuti radnik, novinar, političar i obrtnik na tranziciju gledali, gotovo zajednički, kao nešto novo, kao bolju, mirniju budućnost, a da su previdjeli prave tendencije koje su im se razvijale pred očima.

Naglasimo, kontekst ovog pojma kako ga shvaćamo u članku je sljedeći - radi se zapravo o povijesnom lomu, umjesto tek prijelazu iz "samoupravnog socijalizma" u kapitalistički sistem tržišne ekonomije. Dakle, ovdje stavljamo analitički naglasak na diskontinuitet, odnosno tvrdimo da je prijelaz dio povijesnog loma. Također, detektiranje ključnoga političkog pojma tranzicije i pripadajućih mu političkih pojmova ne dolazi a priori, nego naknadno, istraživanjem procesa koji su se dogodili prije tri desetljeća i dekodirajući njihove interpretacije.

11 "U prikrivajućoj se terminologiji...istovremeno iskazuje mehanizam mistifikacije, a njegovo spoznavanje daje mogućnost da se otkrije politički slang kao (nehotično ili hotimično, svjesno ili nesvjesno) prikrivanje suštinskog i skretanje pažnje od najvažnijeg" (Kosik, 2007: 99, kurziv u originalu). 


\subsection{Politička (demokratska) tranzicija}

Započinjemo analizom pojma političke tranzicije čija je glavna osobina demokratizacija kao proces koji vodi demokraciji. Kako jedan pojam nastaje i u borbi s drugim pojmom koji teži prevladati, demokratizacija zadobiva smisao onda kad se protivnički koncept interpretira kao nedemokratski, kao onaj kojemu upravo nedostaje demokratizacija. Iz te perspektive, smatra se, najveći dio problema rješiv je jednom kad se omoguće demokratski procesi. ${ }^{12}$

Autorica koja je u Hrvatskoj najviše pisala o demokratskoj tranziciji je politologinja Mirjana Kasapović. Pristup analizi demokratske tranzicije je dvostruk - "strukturalistički", kojim se analiziraju političke institucije te "procesualistički", kojim se analizira djelovanje aktera. No, vremenom se razvio i treći smjer koji je neka vrsta sinteze prethodnih dvaju - "institucionalna analiza koja je orijentirana na aktere", to jest "analitičko povezivanje političkih struktura, procesa i sadržaja" (Kasapović, 1999: 223). Ako bismo se kratko zadržali na toj razini, možemo istaknuti bitnu metodološku napomenu prof. Kasapović koja je od interesa i za ovaj rad. Kad, navodeći Philipa C. Schmittera, dijeli demokratsku tranziciju u tri faze, liberalizacijsku, demokratizacijsku i konsolidacijsku, onda Kasapović naglašava da "tranzicija i konsolidacija nipošto nisu 'dva jasno razgraničena procesa', to jest dva procesa među kojima postoji točno utvrdiva granica. Ta se dva procesa stvarno preklapaju, a konsolidacija otpočinje i prije no što je potpuno dovršena demokratizacija" (Kasapović, 1999: 227, kurziv autorov). ${ }^{13}$ To treba imati na umu u daljnjoj konkretizaciji političkog koncepta demokratske i ekonomske tranzicije.

Vlastiti pristup konceptu demokratske tranzicije u Hrvatsku, Kasapović temelji na kontekstualizaciji koja joj omogućuje analizu samog sadržaja tog koncepta. Međutim, dok analitičari ekonomske tranzicije polaze od tzv. ekonomske povijesti, Kasapović se fokusira na političku povijest hrvatske formalne politike od sredine osamdesetih godina 20. stoljeća (Kasapović, 1991: 28). Prva obuhvaća razdoblje 1985. - 1989., a druga 1989. - 1990. Godina 1989. jest razdjelnica jer su te godine intenzivirani procesi unutarnje fragmentacije državnopolitičkog poretka, kao i procesi profiliranja političke opozicije. Te godine glavni uvjeti formalnog restruktu-

12 Za pokojnog ekonomista Branka Horvata demokratizacija društveno-političkog sustava bila je nužna da spriječi revoluciju u procesu restauracije, pri čemu bi glavnu ulogu igrala "konsenzualna demokracija (odlučivanje većine uz uvažavanje mišljenja manjine)" (Horvat, 1995: 66).

13 Otud Kasapović uvodi pojam "anokracije" da bi prijelazni karakter naglasila još jednom. "Anokracija je mješoviti tip vladavine, koji sadrži elemente starih autokracija i novih demokracija, odnosno predstavlja 'mješovite oblike formalne demokracije i sadržajne neliberalnosti demokracija' (Beyme, 1990). Anokratski sustav u Hrvatskoj nastao je voljom dominantne stranke koja je pobijedila na prvim slobodnim izborima 1990., a koja je bila nacionalistička grupacija s dvojbenim političkim ciljevima (Beyme 1994)." (Kasapović, 2001: 18). 
riranja "političkog polja" bili su ispunjeni, posebno odlukom SKH da se raspišu višestranački parlamentarni izbori. Daljnja kontekstualizacija uključuje "tri kolektivna politička aktera: institucionalne subjekte, nacionalne pokrete i inicijative za građanska prava, a oni djeluju na dvije političke razine - na razini formalne, institucionalne politike i neformalne, neinstitucionalne politike" (Kasapović, 1991: 16).

Sadržaj demokratske tranzicije u kasnijim analizama Kasapović nadopunjuje kroz faze "upravljane tvorbe političkih institucija" (1996: 94, 95). To su prva faza, koja je trajala od siječnja do svibnja 1990. i u kojoj je odlučan utjecaj na tvorbu prvih demokratskih političkih institucija imala reformirana komunistička organizacija te druga faza, koja je trajala od smjene vlasti u svibnju 1990. do usvajanja novog ustava u prosincu 1990. i u kojoj je presudan utjecaj na tvorbu političkih institucija imala nova politička elita, kroz novu vladajuću stranku. Koliko se period sljedećih godina dinamizirao, ukazuju nam obilježje "hiperelektoralizama (provedena su četiri ciklusa izbora za prvi dom parlamenta (1990., 1992., 1995. i 2000.) i još dva ciklusa za drugi dom (1993. i 1997.), pa tri ciklusa predsjedničkih izbora (1993., 1997., 2000.) te jedan nacionalni konstitutivni plebiscit (1991.) i obilježje "jakog institucionalnog reformizma" (promijenjeni su svi glavni modeli sustava izbora za prvi dom parlamenta: sustav apsolutne većine (1990.), kombinirani sustav s jednakim omjerom većinskih i listovnih mandata (1992.), kombinirani sustav s pretežnim udjelom listovnih mandata (1995.) i razmjerni izborni sustav (1990.))" (Kasapović 2001: 26, 27). Znači, različitim interpretacijama stvarni procesi poprimaju i različite sadržaje, ovisno o perspektivi iz koje su analizirani. Dok je maloprije fokus bio više na demokratskoj tranziciji nakon trenutka u kojem bi ona nominalno trebala otpočeti, dakle nakon dolaska na vlast pobjednika prvih višestranačkih parlamentarnih izbora, sada možemo vidjeti kako je interpretiran sadržaj neposredno uoči tog momenta. I ključna osobina već je bila uočljiva: nove, promijenjene okolnosti osvjetljavaju politiku ne kao onu koja se vodi u "općem nacionalnom interesu", nego kao onu koja se vodi u "jugoslavenskom, a nauštrb nacionalnog interesa" (Kasapović, 1991: 31). ${ }^{14}$

Došlo je do realizacije, do ozbiljenja načela da se u Jugoslaviji okvir političkog djelovanja "određuje nacijom" i da je "ravnopravnost uvedena kao atribut suodnosa nacija, a ne pojedinaca" (Puhovski, 1990: 151, 150, 160). Dakle, polazi se od nacije, ne od državljanina "kao isključivog političkog subjekta" (Puhovski, 1990). ${ }^{15}$ I budući da se politički prostor u Hrvatskoj nije restrukturirao i rekonstituirao, nego

14 Taj se antagonizam može uočiti već, kako kod Slavena Letice (Danas, 1. siječnja 1991: 21), tako i kod intervjua Žarka Domljana (Danas, 26. veljače 1991: 18), gdje obojica o tadašnjem saveznom premijeru Anti Markoviću pišu da jedina pozitivna stvar njegova mandata može biti ako svoju ulogu svede na onu "stečajnog upravitelja" Jugoslavije.

15 Presudan je Ustav iz 1974. koji je "nacionalnost učinio temeljnom političkom kategorijom, a nacionalizam odlikovanom politikom” (Puhovski, 1988: 5). 
"strukturirao i konstituirao", njegovo strukturiranje se odvilo u znaku "retradicionalizacije", u "organizacijskom, političkom i ideologijskom pogledu" (Kasapović, 1991: $34,35)$.

Prema tome, sadržaj se transformirao od ideje uspostave alternativnih oblika društvenosti (Močnik, 2016), preko pokreta za uspostavom novih konstitutivnih oblika (Kasapović, 1991), pa do težnje za tržišnim društvom (vidi Prpić, 1988), a sve u okviru nacije kao političkog subjekta (Puhovski, 1990).

Ako bismo pak pojam političke tranzicije sagledali nešto šire, u odnosu na kapitalistički i socijalistički sistem, tada se pojavljuju sljedeće zanimljive interpretacije pomoću pojma kontrarevolucije. Naime, legitimno je pitanje kako još možemo definirati promjene povijesnog loma 1989./1991., osim kao političku, odnosno ekonomsku tranziciju. U ovom smo radu objedinili ova dva pojma u jedan ključni pojam tranzicije, napomenuvši pritom da je aktualna podjela metodološka i da je stvarnost cjelina. Koliko je znakovit taj odnos između interpretativne podjele i stvarne cjeline, dobro ilustrira češki filozof Karel Kosik napisavši da je "značaj, ali i historijska ograničenost (čeških, op. autora) disidenata u tome, što su zajedno s obnovom demokracije restaurirali kapitalizam" (Kosik, 2007: 284).

Pri pokušaju cjelovitog definiranja promjena, Puhovski daje interpretaciju da je "pobijedila kontrarevolucija". Ona se očituje u tome što je "pobijedila gotovo opća želja da se više ne živi pod režimima koji se legitimiraju revolucijom, a svojim podanicima nameću stegu koja nije zakonski poopćiva. $S$ druge pak strane, zato što se ovaj zahtjev za ponovnim uspostavljanjem 'mirnog života' nerijetko morao i sam probijati koristeći quasirevolucionarne metode" (Puhovski, 1990: 186). Istina, Puhovski u tekstu govori u Istočnoj Europi, ali ne odnosi li se to i na Jugoslaviju, to jest Hrvatsku? Polazeći iz druge, klasne perspektive, Močnik piše da pobijedila "kapitalistička kontrarevolucija na socijalističkoj poluperiferiji" (Močnik, 2016: 299). Vrlo bi se vjerojatno pritom i Močnik složio s Puhovskim, jer su se ti režimi doista legitimirali revolucijama, ali je njegov naglasak na klasnom sadržaju, u tome da je na djelu povratak kapitalizma(u), to jest njegova obnova.

\subsection{Ekonomska tranzicija}

Pojam ekonomske tranzicije privukao je više pozornosti ekonomista i novinara. Građanima je taj pojam bio manje sporan, a više in je zanimala politička sfera - nacionalno pitanje i odnos prema jugoslavenskoj federaciji. Treba napomenuti da se ekonomska tranzicija iscrpljuje u ukupnoj društvenoj promjeni, a ne samo u promjeni ekonomskog sistema - kako se može uočiti iz dominantnog narativa. No, upravo je ta proturječnost - da je promjena vlasničkih odnosa korjenit proces, ali budući da se implementira u ekonomskoj sferi, onda izgleda tek kao reforma 
- u bitnom odredila dinamiku transformacije pojma (ekonomske) tranzicije. Njega određuje nekoliko glavnih elemenata: privatno vlasništvo, društveno vlasništvo, tržišna ekonomija, pretvorba i privatizacija. Dakako, svaki od tih pojmova u datom trenutku i sam postaje političkim pojmom, ali ovdje su uzeti kao konstitutivni elementi glavnog koncepta ekonomske tranzicije, oko kojeg se centriraju. Društveno je vlasništvo, koje u ovom trenutku već postaje prošlo vrijeme, navedeno utoliko što se njegovom kritikom postupno izgrađuje novi koncept, odnosno njegovim likvidiranjem potvrđuje se privatno vlasništvo, a putem njega i sama tranzicija.

Kako se kretala transformacija koncepta ekonomske tranzicije? Presudno je išla preko institucije privatnog vlasništva. ${ }^{16}$ Središnji moment tog pojma uza se vezuje poduzetništvo (kao nešto neodvojivo od privatnog vlasništva), a s njim efikasnost i racionalnost poslovanja, dok se završava vjerom u napredak društvenog blagostanja. No, Jugoslavija kao federacija i Hrvatska kao njezina jedinica temelje svoj ekonomski sistem na društvenom vlasništvu. Stoga se tranzicija prema privatnom vlasništvu (zapravo, prema kapitalizmu) ne može verbalizirati zazivanjem same tranzicije, nego se najprije u nju ubacuje sadržaj, a taj je upravo ovaj navedeni. Slično se razvija i narativ.

Na saveznoj razini krajem osamdesetih godina 20. stoljeća već je jasno da su promjene nužne i da će one ići u smjeru reforme društvenog vlasništva. Vrhunac procesa podudara se s dolaskom premijera Ante Markovića, čija vlada inicira spomenute reforme. Za njega se kriza ponajviše odigrava u ekonomskoj sferi i ako nju uspije riješiti, smatra da će najveći dio političke krize također biti riješen. Pritom ima podršku ekonomista na saveznoj razini. S druge strane, svaka od socijalističkih republika smatra da je problem ponajprije politički, a taj dualizam umnogome stvara napetosti. Krajnji rezultat jest politička pobjeda nacionalističkih opcija na višestranačkim izborima i drastična revizija inicijalne reforme društvenog vlasništva, odnosno, u hrvatskom slučaju, kreće pretvorba i privatizacija. Pod drastičnom revizijom mislimo na to da nova vlast uklanja pretpostavku reforme društvenog vlasništva tako da započinje njegovo ukidanje.

16 Bitna je ovdje knjiga novinara Drage Buvača Povratak u kapitalizam (1990.). Već i sam naslov upućuje na to da je autoru prilično jasno što se događa. Međutim, namjera autora je teorijskopraktičnan doprinos obnovi kapitalizma da bi se ova odvijala što efikasnije. U tom se smislu knjiga sastoji ne samo od opisa prijašnjih privatizacijskih iskustava na Zapadu (ali $s$ jasnim razlikovanjem između kapitalističkih zemalja), teorijske razrade privatizacijskih modela za Jugoslaviju, nego i od pokušaja "razotkrivanja ideoloških i teoretskih pogrešnih premisa od kojih polaze pojedini socijalistički modeli privatizacije" (Buvač, 1990: 44). Pritom Buvač čvrsto brani i razvija argumentaciju za privatno vlasništvu, a protiv društvenog vlasništva. To, uostalom, jasno kaže: "jedini cilj ovog modela (koji Buvač predlaže, op. autora) jest da se do kraja uništi društveno vlasništvo" (Buvač, 1990: 114). 
Počela se ostvarivati sadržajna transformacija koncepta ekonomske tranzicije. Kao doprinos problematici, predložili bismo podjelu te transformacije u tri faze. Smatramo da su podjele tranzicijskog procesa koje su polazile od koncepta političke tranzicije isključujući pretpostavku povijesnog loma (Kasapović, 2001; Søberg, 2007), obradile samo dio postojeće problematike. Stoga se mogući doprinos očituje u faznoj podjeli konstrukcije sadržaja ekonomskog koncepta tranzicije. Podjelu temeljimo na kvalitativnom razvoju, neodvojivom od povijesnog loma 1989./1991., dakle tvrdimo da su se te promjene snažnog intenziteta odvijale prilično rapidno u samo tri godine. Daljnji tijek događaja već je nosio biljeg tih promjena. U tome je njihova važnost. Slažemo se i s opaskom nekih naših autora da su već spomenute tranzicijske faze kod Søberga "iskazane kao temporalne kategorije, tj. u povijesno-razvojnoj perspektivi, a ne u smislu faza tranzicijskog modela". Zato je manje riječ o "konceptualiziranju neke nove tranzicijske faze ili o redefiniranju postojećeg teorijsko-analitičkog koncepta" (Lalić, Maldini i Andrijašević, 2010: 44). U tom smislu naša podjela jest pokušaj doprinosa konceptualiziranju tranzicijskog modela, ali onog prvotnog, to jest njegova prapočela.

Prva faza, koja u ovom kontekstu dolazi do izražaja tijekom 1989., dakle kad politička situacija postaje sve napetijom, jest rasprava o nužnosti podizanja efikasnosti u sistemu, razvoju poduzetništva i jačanju privatnog vlasništva. Druga faza, koja evoluira na prijelazu iz 1989. u 1990. i uoči višestranačkih izbora u Hrvatskoj, jest zagovaranje ravnopravnosti tipova vlasništva, ali zapravo težnja za ukidanjem društvenog vlasništva u korist privatnoga, i sve glasnije zagovaranje nužnosti tranzicije (u skladu s istočnoeuropskim i srednjoeuropskim trendovima). Treća faza je rasprava o pretvorbi i privatizaciji nakon dolaska HDZ-a na vlast te rasprava o sudbini 'naslijeđene' društvene imovine, a traje od proljeća 1990. pa sve do uspostave političke kontrole HDZ i njemu bliskih poduzetnika nad ekonomijom.

Da bismo obradili spomenute faze, ponajviše ćemo, služeći se metodom analize sadržaja, konzultirati tjednik Danas i mjesečnik Banku. Izabrali smo tjednik Danas zato što je $u$ ono vrijeme bio kvalitetan i popularan tjednik koji je pratio politička i ekonomska zbivanja iz cijele Jugoslavije. S druge strane, mjesečnik Banka izabrali smo nasuprot Danasu. On se bavio gotovo isključivo događanjima u Hrvatskoj i to posebno ekonomskog i politekonomskog karaktera. Dok u Danasu postoje tendencije koje tranziciju promatraju iz savezne perspektive, s postupnim jačanjem republičkih perspektiva, Banka navodi nešto užu perspektivu. Zapravo, analiza sadržaja Banke artikulira poziciju svog osnivača Zagrebačke banke, da bi se ta pozicija vremenom približila poziciji same hrvatske države u borbi za vlastite ekonomske interese. K tomu, tjedna i mjesečna izlaznosti tih novina, utjecala je donekle i na to da su se filtrirali tada aktualni i važni od nevažnih događaja. 
Analizirani novinski sadržaj, točnije 13 tekstova iz 12 brojeva tjednika Danas te 10 tekstova iz pet brojeva mjesečnika Banka, jesu kolumne i intervjui (puna lista nalazi se u Dodatku). Najviše su nas zanimale kolumne i intervjui onih ličnosti koje su izravno stvarale ili utjecale na stvaranje kapitalističke ideologije, odnosno koje su svojim pisanjem ubrzavale tadašnje ekonomske procese. Te ličnosti bili su neki od saveznih ekonomista poput Ivana Ribnikara, Ljubomira Madžara, Dragomira Vojnića koji su tih godina najviše prisutni u medijskom prostoru, pa novinari Dimitrije Boarov, Ratko Bošković, Drago Buvač, Ivo Jakovljević i drugi. Smatramo da su za svrhe ovog članka kolumna i intervju ipak dvije najznačajnije vrste novinskog sadržaja. Kolumna omogućuje autoru da se autentično i dovoljno široko, a time i kvalitetnije izrazi, odnosno ostvari svoj utjecaj na čitatelje. S druge strane, intervju sa svojom formom dijaloga zapravo nam omogućuje da uočimo ne samo poziciju onog koji odgovara, nego i onog koji pita ili komentira. U slučaju našeg članka to su bili već spomenuti novinari iz čijih se pitanja i komentara otkriva približno jednaka pozicija kao i kod ekonomista koje pozivaju za sugovornike. Zato se onda na trenutke čitatelju opravdano čini da su ti intervjui vrlo sinkronizirani i da se nadopunjuju, dakle da nema komunikacijske napetosti.

Analiziran sadržaj odnosi se na razdoblje od lipnja 1989. do veljače 1992., a važno je bilo ukazati na razvijanje određene ideološke matrice koja je utisnula sadržaj u proces tranzicije, dakle zbog koje se pod tranzicijom u jugoslavenskim okolnostima smatralo ukidanje društvenog vlasništva i prijelaz na privatno poduzetništvo.

Također, trebalo je izdvojiti određene brojeve obaju časopisa, neovisno o nekoliko desetaka pregledanih i pročitanih brojeva, jer su u njima ideje spomenutih novinara-analitičara, te jugoslavenskih ekonomista, najviše dolazile do izražaja. Izdvojeni brojevi korespondirali su s onim vremenskim trenutcima koje su obilježili konfrontacije politekonomskih tendencija. Stoga su u tekstovima u tim brojevima, više nego u ostalima, nastale napetosti bile uočljivije pa je stoga njihov izbor bio strateška odluka, unatoč relativno malom broju tekstova (ukupno 23) koji su u konačnici analizirani.

\subsubsection{Analiza tjednika Danas}

Već u ljeto 1989. godine Danas donosi intervju Ratka Boškovića s poznatim slovenskim ekonomistom Ivanom Ribnikarom i tako sudjeluje u izgradnji političkog koncepta tranzicije. Iznoseći svoj "teorijski okvir", profesor Ribnikar konstatira: "poduzeće ne može nastati ako netko ne uloži svoju imovinu" (Danas, 27. lipnja 1989: 27). "Društveno se vlasništvo nikako ne može spasiti. Ono predstavlja nastranost jugoslavenskog sistema." I ako već mora biti nešto što ima pojam "društveno", neka ostanu onda društvena poduzeća, ali neka se definiraju kao "poduzeća u 
kojima postoji suupravljanje radnika. Ne isključivo upravljanje radnika" (Danas, 27. lipnja 1989: 28). ${ }^{17} \mathrm{Na}$ kraju, i sam novinar Bošković sugestivno pita profesora Ribnikara: "Koliko dugo ćemo morati živjeti sa spoznajom da je dominantan dio naše jugoslavenske privrede ideološki relikt namijenjen odumiranju?" (Danas, 27. lipnja 1989, kurziv autorov). ${ }^{18}$ Međutim, profesoru Ribnikaru postalo je poprilično jasno kako bi se stvari mogle razvijati. Krajem 1990. ustvrdio je da su u "jugoslavenskom slučaju pomiješana značenja... U Jugoslaviji privatizacija znači nacionalizaciju, jer novac od prodaje tzv. društvenog kapitala može ponovno da se uloži u isto ili neko drugo poduzeće, ali posredstvom države!" (Danas, 6. studenog 1990: 24, kurziv autorov).

Predrag Vranicki u povećem članku upozorava da je najbitnije "osloboditi društveni sektor od državnih uplitanja i ... da se taj sektor osposobi da funkcionira prema kriterijima svjetskog tržišta..." (Danas, 21. studenog 1989: 29). Vranicki ne prelazi posve na stranu prokapitalističke ideologije, ali se vidi da je u teorijskom rascjepu, budući da je ustrajan u zadržavanju društvenog vlasništva, a istodobno je njegova poruka, u tadašnjem kontekstu, smanjenje uloge države u privredi. Za to nam pruža i argumentaciju da je "etatističko uplitanje, planiranje i svestrano reguliranje proizvodnje, određivanje cijena i dohotka, sputavalo samostalnost, inicijativu i samoupravljanje koje uopće nije došlo do stvarnog i historijski adekvatnog izražaja" (Danas, 21. studenog 1989: 28). Ta poruka u cjelini zapravo je usmjerena, nesvjesno, prema privatnom vlasništvu, na što nas upućuje i sam Vranicki kad osobine tržišnog privređivanja i zakona vrijednosti pripisuje samoupravljanju, a na štetu planske regulacije.

Ova razmišljanja Vranickog kasnije razvija i Branko Horvat koji je jasan: "Ono što treba uraditi jest razviti tržište (ustvari dovršiti tržišnu transformaciju započetu 1952. i napuštenu poslije 1970.) i osamostaliti poduzeće. To se može učiniti for-

17 Možemo uočiti zamagljivanje pokušaja ukidanja društvenog vlasništva, tako što će se u pojam društvenog poduzeća implementirati drukčiji, prokapitalistički, sadržaj. Zanimljivo, slično govori i makedonski ekonomist Vladimir Gligorov: "umjesto socijalizma, dobili bismo jedno mješovito društvo. Umjesto samoupravljanja na nivou poduzeća, imat ćemo, eventualno, oblike industrijske participacije" (Danas, 23. siječnja 1990: 18, kurziv autorov). Međutim, u nastavku ovog intervjua Gligorov ne koristi eufemizme pa je ustvrdio: "ključna stvar je pitanje svojine... to što je temeljno za socijalizam treba napustiti” (Danas, 23. siječnja 1990: 17). "Potrebno je, dakle, ukloniti sve prepreke za postojanje privrednog sistema zasnovanog na privatnoj svojini” (Danas, 23. siječnja 1990: 18). Naposljetku poentira: "pitanje hleba je neposredno povezano najpre sa pitanjem uklanjanja društvene svojine, odnosno njene privatizacije, i potom sa pitanjem uvođenja demokratije" (Danas, 23. siječnja 1990: 19).

18 Isti će novinar nešto kasnije ustvrditi: "Povijest je ove godine svjedok i činjenica da komunizam ili 'put' do njega ni u jednoj zemlji nije uspio, ni ekonomski ni politički, zbog jednostavnog razloga što je ukinuo konkurenciju u ekonomiji i u politici, udaljavajući time društvo od njegova prirodnog stanja" (Danas, 6. studenog 1990: 24, kurziv autorov). 
miranjem društvene korporacije. ... A da li će poduzeće biti u privatnom ili nekom drugom vlasništvu, to ne određuje (niti smije određivati!) država administrativnim putem, već to rješava tržište koje će konkurencijom izdvojiti efikasne oblike vlasništva" (Danas, 29. siječnja 1991: 24). Možemo reći da iza tih razmišljanja Vranickog i Horvata stoje dosljedni marksisti kako su u onom trenutku povijesnog loma sami sebe shvaćali i koji se bore za - očuvanje samoupravljanja (i društvenog vlasništva) kao jezgre socijalizma.

Bitku na saveznoj razini za nastajući koncept nastavlja i Boarov u svojim člancima i intervjuima. U jednom od njih uočava: "Na trećem Brionskom savetovanju jugoslovenskih ekonomista definitivno je potpuno preovladalo shvatanje da nikakav novi razvojni ciklus nije moguć dok se radikalno ne transformiše društvena svojina" (Danas, 15. svibnja 1990: 28). Uz potvrdu da su jugoslavenski ekonomisti većinski za privatno vlasništvo, možemo primijetiti i način kako se to opravdava - bez toga, naime, nema ništa od razvoja. ${ }^{19}$ Nakon toga, slično kao i Bošković ranije, Boarov će pitati sekretara Saveza ekonomista Jugoslavije Nebojšu Savića za mišljenje: "Potreban je potpuno novi pristup, sa pretežnim osloncem na preduzetnički model razvoja, a takav pristup duboko je povezan sa svojinskom transformacijom" (Danas, 15. svibnja 1990: 29).

U drugom i povećem intervjuu s poznatim ekonomistom i tadašnjim savjetnikom premijera Markovića, Ljubomirom Madžarom također se dotiče teme privatnog vlasništva, poduzetništva i tržišne ekonomije. Kaže Madžar: "Vlasnik je taj koji stavlja glavu na panj... Vlasništvo je duša privrede” (Danas, 10. srpnja 1990: 27).

\subsubsection{Analiza mjesečnika Banka}

S druge strane, Banka promovira glavnu poruku: privreda se guši zbog državnog stiska. Novinar Ante Gavranović tako piše: "Sadašnje stanje - to treba konačno otvoreno reći - katastrofalno djeluje na ukupno privredno tkivo jugoslavenske privrede i zemlje u cjelini... Politički dogovor o izlasku iz krize - a to je ono što traži privreda u svim sredinama - osnovni je uvjet da se riješi i privredna kriza. Na kraju, postavimo jedno pitanje: dokad će politika 'silovati' privredu i nametati joj terete koje ona više ne može podnijeti?" (Banka, 1991, 2(1): 37).

U metodološki određenoj drugoj fazi, sociolog Josip Županov ispravno dotiče problem kad podvlači da je kod tranzicije zapravo riječ o "povratku u kapitalizam" (Županov, 1995: 59). No, onda se u daljnjoj razradi problema vraća korištenju

19 Nešto ranije, Vladimir Goati opravdava privatno vlasništvo iz političke perspektive na izrazito privlačan način, preko pojmova slobode i nezavisnosti pojedinca: "Privatna svojina obezbeđuje značajnu nezavisnost pojedinaca, zajemčujući prostor njegove slobode od nasrtaja političkih moćnika" (Goati, 1989b: 170). 
političkog koncepta tranzicije. Za njega je tranzicija put u superiorniji $\operatorname{sistem}^{20} \mathrm{i}$ "mora značiti prijelaz od potpunog političko-ekonomskog monopola na 'regulirano tržište' ili čak 'socijalno tržište'” (Županov, 1995: 64). Put do tranzicije naglašeno ide preko privatizacije, a ona u praksi znači: "a) institucionalno priznanje privatnog poduzetništva (koje u socijalizmu uglavnom nije bilo dopušteno) i time opću dozvolu da svaki građanin može osnovati i voditi privatno poduzeće, b) pretvorbu državnih i društvenih poduzeća u privatna" (Županov, 1995: 66).

Ne treba smetnuti s uma i tadašnji kontekst, čija se presudna dinamika odvijala na razini federacija - republike, o čemu je poticajno pisala Mirjana Popović. Njezini članci pomalo odudaraju od prevladavajućeg tona mjesečnika Banka. Dobro je zamijetila ne samo razinu napetosti između SR Hrvatske, tj. nacionalne razine, i SFRJ, tj. savezne razine, jer to jest bilo očito - nego i značenje te napetosti za unutrašnje, hrvatske procese uvelike pokretane težnjama političkih aktera. Kod svih republika, pa i hrvatske postoji: "Dvojni odnos prema saveznoj vladi i njezinu prvom čovjeku, koji se očituje upornim inzistiranjem da SIV učini ovo ili ono (naprimjer da olabavi monetarnu politiku, devalvira dinar i sl,), uz istodobno nepoštivanje propisa što ih SIV predlaže..." (Banka, 1991, 2(1): 6). Inače, ta pojava nije toliko nova i ne odnosi se samo na nova, nacionalistička vodstva jer o njoj analitički pisao već spomenuti Goati 1989. godine: "Republički lideri, suprotstavljeni liderima drugih republika, nastoje da dobiju što širu podršku u svojoj sredini. Konfliktnost spolja traži homogenizaciju iznutra. U težnji da pospeše internu homogenizaciju politički vođi vešto koriste massmedie koji u pravom medijskom ratu potenciraju utisak o ugroženosti vlastite republike od drugih" (Goati, 1989a: 11). Kako se stvari ne razvijaju mehanički, onda politička igra nije a priori koordinirana s privrednom igrom, to se tek trebalo ostvariti različitim političkim sredstvima. Vidi se to iz činjenice koju Popović navodi odmah u sljedećem broju: “...privrede svih republika... preko savezne privredne komore zahtijevaju: ukidanje svih propisa koji zaprečuju funkcioniranje jedinstvenog jugoslavenskog tržišta. To u biti znači opoziv svih republičkih mjera kojima je privreda korištena radi političkih pritisaka" (Banka, 1991, 2(2): 70).

Što se tiče posljednje, treće faze, ona se očituje u glorifikaciji tržišta i nužnosti privatizacije, dok se pritom intenzivira ekonomska kritika bivšeg sistema ${ }^{21}$ Nužnost privatizacije odnosi se presudno na onu imovinu koju je nova hrvatska država zapravo nacionalizirala kroz pretvorbu društvenog vlasništva i koju namjerava razdi-

20 "Propast komunističkog sustava otvorila je i drugi proces koji je bitno povezan s problemom modernizacije - proces tranzicije iz socijalističkog društva u moderno kapitalističko društvo, u društvo tržišne ekonomije i privatnog vlasništva" (Županov, 1995: 169).

21 Jedna od direktnijih kritika iz pera je novinara Damira Ostovića: "Komunistička društva nisu propala samo zbog nepostojanja privatnog vlasništva i otvorene konkurencije, nego i zbog potpunog kolapsa infrastrukture" (Banka, 1992, 3(4): 16). 
jeliti krugu utjecajnih ljudi unutar i blizu HDZ-a. Retorika stoga ide u dva smjera. Ivica Gaži, tadašnji glavni čovjek Hrvatske gospodarske komore, ne propušta naglasiti da "znademo što su nam resursi... i treba da ih samo prepustimo tržišnoj ekonomiji..." (Banka,1991, 2(5): 21). Ili, poznati novinar Chris Cviic u intervjuu za Banku: "prema mojem mišljenju strateška orijentacija mora biti - Hrvatska apsolutno ne može drukčije - slobodno tržište..." i pritom vrlo zanimljivo (posebno iz konteksta nakon 2008.) dodaje da je "negativna prednost privatnog poduzetništva baš to da sve što ne uspije propadne, ali onda to snosi onaj koji je to poduzeo i njegovi dioničari, a ne podnosi cijeli narod. To je ogromna prednost" (Banka, 1992, 3(1): 5). Zatim Ivo Jakovljević koji početkom devedesetih uopće nije dvojio: “... važno je da hrvatska ekonomija u kratkom roku prijeđe u privatne ruke te da kao visoko konkurentna bude otvorena za sve europske tokove" (Danas, 17. ožujka 1992: 18). lako je taj njegov poziv usmjeren isključivo protiv HDZ-ove nacionalizacije društvene imovine, on se i dalje uklapa u tadašnji dominantni sadržaj političkog koncepta tranzicije.

Nakon podržavljenja društvenog vlasništva osnovna je dvojba bila treba li tu imovinu raspodijeliti ili prodati. Možemo zaključiti da su protivnici HDZ-a više zagovarali raspodjelu, pokušavajući u javnom prostoru što jače utjecati na denacionalizaciju imovine. Izdvojit ćemo Krešimira Džebu, potpredsjednika HNS-a, koji navodi: "Jednostavno ne nalazim riječi kojim bih kvalificirao odlučnost HDZ-ovske vlasti da nastavi 'privatizaciju' time što će 30. lipnja (1992., op. autora) oko 90\% poduzeća prenijeti u državno vlasništvo. Treba li to nazvati putem iz socijalizma u socijalizam? ...Jedini izgledni model privatizacije u postkomunističkim zemljama jest da se radnicima i menadžerima besplatno podijele dionice" (Danas, 17. ožujka 1992: 15). Ili, opet novinar Jakovljević, koji također upozorava na mogućnost povratka na socijalizam: "Ako stranci nemaju interesa za kupnju većeg broja ovdašnjih ex-soc-poduzeća, a domaći kupci nemaju dinara, s kakvom tehnikom imovinske pretvorbe u poslijeratnom razdoblju Hrvatska može izbjeći prijetnju povratka na socijalizam bez tržišta (pod pritiskom masovne bijede)?" (Danas, 3. ožujka 1992: 27). ${ }^{22}$

22 Zanimljiva je ovdje izjava Dragomira Vojnića u istom broju Danasa: "Danas je očito da privatizacija mora biti miks besplatne razdiobe dionica prodaje dionica sa i bez popusta, te koegzistencije društvenog i privatnog vlasništva" (3. ožujka 1992: 28, kurziv autorov). Podvučeno je očiti contradictio in adjecto, ali nije jasno je li to posljedica Vojnićeve vjere u to što govori ili neka vrsta njegova kompromisa. 


\subsubsection{Poslijeratna obnova i razvoj novih vlasničkih odnosa}

Izdvojit ćemo još jedan moment formuliranja promjena unutar povijesnog loma 1989./1991. O čemu je riječ? Već krajem 1991. i u 1992. probija se logično razmišljanje o obnovi ratom oštećenih područja. Doduše, tada se nije znalo da će i sam rat trajati do 1995., odnosno 1998., ali za ovaj su rad od neprocjenjive važnosti tadašnja razmišljanja i izjave. Suština je zaustavljanje bilo kakve obnove prethodnih (kako se vjerovalo tada, već prevladanih) ekonomskih odnosa, a pokretanju obnove u korist novih kapitalističkih odnosa. Dakle, bitno je to što su akteri osvijestili da su promjene ekonomskih sistema promjene i ekonomskih odnosa. Tako je ministar obnove Slavko Degoricija dao intervju 1992. pod varljivim naslovom "Dobri programi - uspješna obnova". U njemu na jedno od pitanja novinara: "Pretpostavljajući da će poljoprivreda ubuduće imati strateško značenje, da li je i o tome načinjena koncepcija obnove?", Degoricija jasno odgovara: "Sasvim je jasno da na selu neće biti moguće, i da to zapravo nije potrebno, svaki objekt obnoviti nalik na prijašnji izgled. Mnogo je bitnije, a to je naše opredjeljenje, da sada, kada smo zapravo na početku, počnemo stvarati moderne robne proizvođače" (Banka, 1992, 3(1): 10).

I nešto dalje $u$ istom broju novinarka Suzana Mrkobrada slično argumentira. Njezina argumentacija nije usmjerena samo na poljoprivredu, nego na ukupnost ekonomskih odnosa. Kako piše: "I u obnovi će se voditi briga o razvoju malih proizvodnih i uslužnih poduzeća. Naime, ako je ratom srušen neki veliki pogon ili tvornica (pr. TLM u Šibeniku), teško je nadomjestiti proizvodnju i uposliti ljude. Hrvatska nema i neće dugo imati novce da gradi gigante. Pitanje je i da li je to potrebno. Zato mjerama tekuće ekonomske politike...valja omogućiti stvaranje malih proizvodnih i uslužnih poduzeća..." (Banka, 1992, 3(1): 79). Da bi naposljetku u sljedećem broju ekonomist Mate Babić poentirao: “...obnova porušenih privrednih objekata, čime se uspostavlja stara, predratna struktura, ne dolazi u obzir..." (Banka, 1992, 3(4): 29).

Zanimljivo je primijetiti nešto što može biti i jedna ne manje važna istraživačka teza. Naime, da je hrvatskoj političkoj eliti bilo ključno uspostaviti nove vlasničke odnose i na taj način uraditi rekapitulaciju privrede, pa i u ratno vrijeme. Međutim, ne zato da bi se mogli okoristiti tijekom rata i ratnih događanja. Nego upravo obratno, da su ratno stanje uvidjeli kao odličnu priliku za uspostavu i izgradnju novih vlasničkih odnosa jer prvo, različiti privredni kapaciteti i objekti bivaju oštećeni i tako ih se lakše može preuzeti i drugo, ratno stanje presudno slabi bilo pregovaračku moć zaposlenih bilo njihovu organizaciju iz koje i proizlazi pregovaračka moć.

Konačno u kontekstu ključnog pojma tranzicije, posebno svjesnog i ciljanog djelovanja prema sprečavanju razvoja starih ekonomskih odnosa, značajan je $\mathrm{i}$ 
intervju koji je Ivanu Zvonimiru Čičku početkom 1992. dao ekonomist Dragomir Vojnić. U njemu je jezgrovito definirao pojam tranzicije. Pod tranzicijom, veli Vojnić, "podrazumijevamo sve procese koji su uključeni u preobrazbu socijalističkih društveno-ekonomskih i političkih modela u model suvremene tržišne demokracije koji se temelji na slobodi tržišta, na dominaciji privatnog vlasništva, na parlamentarnoj demokraciji, funkciji pravne države uključuju i sva ljudska prava" (Danas, 11. veljače 1992: 25). Ovdje, kao što se vidi, Vojnić vrlo jasno kaže da je tranzicija cjelovit proces koji uključuje kako ekonomsku tako i političku sferu. O tome on nema iluzija - teorijski. Međutim, u praksi, kao i većinu ekonomista, njega ipak drži određena iluzija: da je ta promjena ponajviše ekonomska, a da politika mora biti svedena na minimum. ${ }^{23}$ Pogrešno je doživljavati proces tranzicije, pa onda i pristupati njegovu istraživanju, s pretpostavkom da je jedna od tih dviju sfera važnija. $\mathrm{Ne}$, i ekonomska i politička sfera jednako su važne zato što čine cjelinu.

Možda prethodno spomenuta logika, da je ekonomija ipak važnija, stoji u pozadini jednoga zanimljivog Čičkova komentara, a još zanimljivijeg Vojnićeva odgovora. Najprije komentira Čičak: "Jedan je američki ekonomist primijetio kako su takvi pojedinci kao što ste Vi i takav institut (Ekonomski institut Zagreb, op. autora) kao što je vaš više pridonijeli rušenju komunizma iznutra nego mnogi pritisci izvana." Vojnić: "Ta konstatacija je točna, pa to i jest razlog što je djelatnost nekih institucija tijekom proteklih godina i desetljeća nosila epitet antikomunističke... Ova orijentacija... je samo pretendirala na to da znanstvenim djelovanjem ubrza pomake $u$ pravcu veće ekonomske efikasnosti i političke demokratičnosti. A to znači u pravcu većih tržišnih i političkih sloboda" (Danas, 11. veljače 1992: 27). Na stranu to što Vojnić ovdje implicira da je tendencija podizanja ekonomske efikasnosti i političke demokratičnosti, uz određene političke okolnosti, uvelike vodila obnovi kapitalizma. Ali za ovaj rad je bitna suština izdvojenog dijela intervjua - da je na izgradnji i razvoju političkog pojma tranzicije bitnu ulogu imao Ekonomski institut, odnosno da su se okolnosti razvoja političkog pojma stjecale i institucionalnim, ne samo izvaninstitucionalnim putevima.

Analizirali smo odabrani novinski sadržaj časopisa Danas i Banka kako bismo obradili tri faze transformacije koncepta ekonomske tranzicije. Rezultati do kojih smo došli nisu neočekivani, posebno s obzirom na međunarodni kontekst, prije svega s obzirom na političke promjene u Istočnoj Europi. Tako smo navodeći razmišljanja (kroz intervjue) i pisanu razradu ideja (putem kolumni) tada etabliranih i poznatih jugoslavenskih ekonomista, slovenskog - Ivana Ribnikara, hrvatskog

${ }^{23}$ "Ako ne želimo riskirati korak nazad, moramo nastaviti proces privatizacije bez vraćanja na državno vlasništvo... Poželjno je... da se neposredno uplitanje države, a posebno politike, u proces vlasničke pretvorbe i privatizacije smanji na što je moguće manju mjeru" (Danas, 11. veljače 1992: 26). 
- Dragomira Vojnića te srbijanskog - Ljubomira Madžara, uputili na svojevrsni konsenzus u vezi prijelazne dimenzije sistema baziranog na društvenom vlasništvu. Dakle, i slovenski i srbijanski ekonomisti, kao i njihovi hrvatski kolege - svi su oni u društvenom vlasništvu vidjeli neefikasnost, a izlaz u privatnom vlasništvu. Situacija je bila dodatno razvijana od spomenutih novinara, Dimitrija Boarova za saveznu razinu te Ive Jakovljevića, Ratka Boškovića i Mirjane Popović za nacionalnu - hrvatsku razinu. Razlika je donekle bila u volji i spremnosti (možda i odvažnosti) da se istaknu postupna ili pak nagla rješenja. Sve usamljenijima bivali su ekonomisti poput Branka Horvata koji su ustrajali na koegzistenciji društvenog i privatnog vlasništva. Konačno, pobjedom HDZ-a, političke opcije koja je beskompromisno zagovarala ukidanje društvenog vlasništva u svojem, ionako oskudnom, ekonomskom programu, od proljeća 1990. otvara se nova dimenzija u vezi procesa pretvorbe i privatizacije te sudbine 'naslijeđene' društvene imovine. Tu dimenziju ponajviše razvijaju novinari Banke koji, zajedno sa svojim sugovornicima, promiču uspostavu novih vlasničkih odnosa nasuprot onih zasnovanih na društvenom vlasništvu.

\section{ZAKLJUČAK}

U radu smo pokušali pridonijeti istraživanju prijelaza iz "samoupravnog socijalizma" u kapitalizam, tako da smo analizirali sadržajnu transformaciju političkog pojma tranzicije. Dosad su napravljene analize demokratske tranzicije, koje se koncentriraju na političku sferu i na događaje obilježene prijelazom iz jednostranačkog u višestranački sistem, ali i stvaranjem države, s jedne strane te analize ekonomske tranzicije kojima je u fokusu ekonomska sfera i događaji obilježeni prijelazom iz sistema društvenog vlasništva u sistem privatnog vlasništva, s druge strane. No, nedostaju analize koje prožimanje političke i ekonomske tranzicije uzimaju kao osnovnu pretpostavku, odnosno koje će povijesni lom 1989./1991. uzeti kao cjelinu i koje će istražiti kretanja u ideološkoj stvarnosti. Kako se dotični povijesni lom ne može spoznati u potpunosti, koristili smo se metodološkim okvirom koji se temelji na kreiranju političkog pojma. Dubljim istraživanjem prepoznali smo tranziciju kao ključni politički pojam povijesnog loma 1989./1991., bez kojeg ni svi ostali koncepti nisu održivi.

Jednom kad smo odredili tranziciju kao taj politički pojam, odmah smo ju podijelili na političku i ekonomsku tranziciju, uvijek imajući na umu pretpostavku da je riječ o metodološkom okviru, ne o stvarnim procesima jer oni, u realnosti, nisu odvojeni. Analizom različite literature, od znanstvenih članaka, knjiga do tjednika i mjesečnika, vidjeli smo kako se godinama mijenjao sadržaj tog pojma, odnosno kako se preobrazio. Tranzicija je obuhvaćala sljedeće konstitutivne elemente: društveno i privatno vlasništvo, privatizaciju i demokratizaciju. Spomenuti su elementi u 
svakom trenutku vezali uza se druge pojmove i tako zapravo pripremali nastajanje kapitalističke ideologije, koja je realizirajući presudnu točku svoga razvoja 'izbacila' na površinu politički pojam tranzicije. Tako je tranzicija postala očitom onda kad je već ideologija efikasno djelovala. Neizmjerna je prednost ove kapitalističke ideologije u činjenici da se i danas pristupajući društvenim procesima s kraja osamdesetih i početka devedesetih godina 20. stoljeća na njih gleda razdvojeno (kao čisto ekonomske i čisto političke procese) i da ih se ne vidi kao drastični društveni diskontinuitet ili rupturu, nego isključivo kao tranziciju.

Smatramo da rad može doprinijeti politološkoj i ekonomskoj znanosti. Doprinos politologiji očituje se time što se $u$ analizi političke sfere disolucije Jugoslavije i nastanka nove države ne zanemaruje ekonomska sfera, nego se nastoji ukazati na ekonomsku odrednicu političke borbe. Također, doprinos ekonomiji (posebno političkoj ekonomiji) manifestira se političkom kontekstualizacijom ekonomskih procesa na prijelazu iz jednoga ekonomskog sistema u drugi. Riječju, tek implementacijom politike u sagledavanju ekonomskih procesa, ponajviše pretvorbe i privatizacije, možemo te procese i razumjeti. Analizom transformacije političkog pojma tranzicije učinjen je taj prvi pokušaj i sveobuhvatne politekonomske analize prijelomnih procesa s kraja osamdesetih i početka devedesetih godina prošlog stoljeća. Sveobuhvatna analiza ne znači, opisujući ekonomiku, dodavati i opis politike, niti politiku jednosmjerno pojašnjavati ekonomikom. Ona se ogleda u tome da konstruira istraživačku strukturu koja omogućuje svakim novim elementom istraživanja, međusobno povezivanje ekonomskih i političkih tendencija društva jer u stvarnosti one i čine cjelinu. Više se ne radi o (političkom) prijelazu iz nedemokratskoga $u$ demokratsko društvo, nego je riječ o (socijalnom i nasilnom) prijelazu iz jednoga, šire definiranog, društva u drugo, pri čemu je demokracija samo jedna od sfera.

\section{LITERATURA}

Buvač D (1990). Povratak u kapitalizam. Model brze privatizacije. Zagreb: Zagrebačka poslovna škola.

Carothers T (2002). The End of the Transition Paradigm, Journal of Democracy, 13 (1): 5-21.

Cifrić I (1996). Tranzicija i transformacija - između norme i prakse, Socijalna ekologija: časopis za ekološku misao i sociologijska istraživanja okoline, 5 (2): 135-153.

Freeden M (2006). Ideologies and Political Theory: A Conceptual Approach. New York: Oxford University Press.

Fukuyama F (1989). The End of History?, The National Interest, (16): 3-18. 
Goati V (1989a). Politički pluralizam u nas - stanje i perspektive. U: Goati V (ur.). Smisao jugoslavenskog pluralističkog šoka. Beograd: Književne novine, 7-21.

Goati V (1989b). Reforma SKJ i političkog sistema. U: Goati V (ur.). Smisao jugoslavenskog pluralističkog šoka. Beograd: Književne novine, 169-184.

Horvat B (1995). Opozicija i konsenzualna demokracija, Politička misao, 32 (3): 64-71.

Huntington S (1991). Democracy's Third Wave, Journal of Democracy, (2) 2: 12-34. https:// doi.org/10.1353/jod.1991.0016

Ilišin V (1998). Demokratska tranzicija u Hrvatskoj, Sociologija i prostor: časopis za istraživanje prostornoga i sociokulturnog razvoja, 36 (139-142): 27-52.

Jameson F (1981). The Political Unconscious: Narrative as a Socially Symbolic Act. New York: Cornell University Press.

Kasapović M (1991). Strukturna i dinamička obilježja političkog prostora i izbori. U: Grdešić I, Kasapović M, Šiber i Zakošek N (ur.). Hrvatska u izborima '90. Zagreb: Naprijed,15-48.

Kasapović M (1996). Demokratska tranzicija u Istočnoj Europi, Demokratska tranzicija i političke institucije u Hrvatskoj, Politička misao, (33) 2-3: 84-99.

Kasapović M (1999). O knjizi V. Pusić "Demokracije i diktature. Politička tranzicija u Hrvatskoj i jugoistočnoj Europi“, Durieux, Zagreb, 1998., 205 str., Politička misao, (36) 2: 223-230.

Kasapović M (2001). Demokratska konsolidacija i izborna politika u Hrvatskoj, 1990.2000. U: Kasapović M (ur.). Hrvatska politika 1990.-2000. Zagreb: Fakultet političkih znanosti,15-40.

Katunarić V (1995). O tranziciji i staroj strukturi društvene moći, Društvena istraživanja: časopis za opća društvena pitanja, (4) 2-3: 265-271.

Kollmorgen R (2013). Theories of Postcommunist Transformation. Approaches, Debates, and Problems of Theory Building in the Second Decade of Research, Studies of Transition States and Societies, (5) 2: 88-105.

Koselleck R (1989). Social History and Conceptual History, Politics, Culture and Society, (2) 3: 308-325. https://doi.org/10.1007/BF01384827

Koselleck R, Fernandez SJ and Fuentes FJ (2006). Conceptual History, Memory and Identity: An Interview with Reinhart Koselleck, Contributions to the History of Concepts, (2) 1: 99-127. https://doi.org/10.1163/187465606783406153

Kosik K (2007). O dilemama suvremene povijesti. Zagreb: Razlog.

Kuljić T (2018). Prognani pojmovi. Beograd: Clio.

Lacan J, Hollier D, Krauss R i Annette M (1987). Television, October, (40): 6-50. https://doi. org/10.2307/778337

Lalić D, Maldini P i Andrijašević I (2010). Otupjelo oruđe: neprimjerenost tranzicijskog koncepta za analizu konsolidacije demokracije, Anali Hrvatskog politološkog društva: časopis za politologiju, 7 (1): 29-49.

Maldini P (2006). Političko-kulturalni preduvjeti demokratizacije, Politička misao, 43 (3): 87108.

Milić V (1989). Mogućnosti političkog pluralizma. U: Goati V (ur.). Smisao jugoslavenskog pluralističkog šoka. Beograd: Književne novine, 55-63.

Mirčev D (1989). Lapidarij o političkom pluralizmu: put u građansku restauraciju ili šansa samoupravne demokratije. U: Goati V (ur.). Smisao jugoslavenskog pluralističkog šoka. Beograd: Književne novine, 65-78. 
Močnik R (2016). Spisi o suvremenom kapitalizmu. Zagreb: SNV

Prpić I (1988). Društvo i država, Naše teme, (32) 5: 1147-1165.

Puhovski Ž (1988). Jugoslavija je neizbježna, Nedjeljna Dalmacija, 11. studenog.

Puhovski Ž (1990). Socijalistička konstrukcija zbilje. Zagreb: Pitanja.

Søberg M(2007). Croatia since 1989. The HDZ and the Politics of Transition. U: Ramet SP i Matić D (ur.). Democratic transition in Croatia: Value Transformation, Education, and Media. Texas A\&M University Press, 31-62.

Županov J (1995). Poslije potopa. Zagreb: Globus. 


\section{DODATAK: ANALIZIRANI TEKSTOVI}

Banka, 1991, 2 (1): Mirjana Popović. Veliki manevri u tijesnim ulicama.

Banka, 1991, 2 (1): Ante Gavranović. Razbijanje vlastitih zabluda.

Banka, 1991, 2 (1): Mirjana Pitarević. Očuvati narodno bogatstvo.

Banka, 1991, 2 (2): Mirjana Popović. Miješana salata s gorčicom.

Banka, 1991, 2 (5): Mirjana Pitarević. Obnova hrvatskog gospodarstva.

Banka, 1992, 3 (1): Chris Cviic. Tržišno gospodarstvo - Condicio sine qua non.

Banka, 1992, 3 (1): Slavko Degoricija. Dobri programi - uspješna obnova.

Banka, 1992, 3 (1): Suzana Mrkobrada. Obnova obrtništva.

Banka, 1992, 3 (4): Damir Ostović. Razvoj infrastrukture.

Banka, 1992, 3 (4): Mate Babić. Ekonomski program neovisne Hrvatske.

Danas, 27. lipnja 1989.: Ivan Ribnikar. Za spas reforme.

Danas, 21. studenog 1989.: Predrag Vranicki. Jugoslavija na raskršću.

Danas, 23. siječnja 1990.: Vladimir Gligorov. Kruha i igara.

Danas, 15. svibnja 1990.: Dimitrije Boarov. Traži se vlasnik.

Danas, 10. srpnja 1990.: Ljubomir Madžar. Glava na panju.

Danas, 6. studenog 1990.: Ivo Jakovljević. Konfiskacija crkvene imovine.

Danas, 1. siječnja 1991.: Slaven Letica. Hrvatska nakon komunizma.

Danas, 29. siječnja 1991.: Branko Horvat. Sedam smrtnih pogrešaka.

Danas, 26. veljače 1991.: Žarko Domljan. Hrvatska može sama.

Danas, 11. veljače 1992.: Dragomir Vojnić. Quo vadis domovino?

Danas, 3. ožujka 1992.: Ivo Jakovljević. Hrvatska na (ras)prodaji.

Danas, 17. ožujka 1992.: Krešimir Džeba. Put u ropstvo.

Danas, 17. ožujka 1992.: Ivo Jakovljević. Čija je Hrvatska? 


\title{
Transformation of the Political Concept of Transition Following the Historical Rupture of 1989/1991 in Croatia
}

\author{
Dimitrije BIRAČ (D) https://orcid.org/0000-0002-3226-9843 \\ Faculty of Political Science, University of Zagreb, Croatia \\ dimitrije.birac@gmail.com
}

\section{ABSTRACT}

This paper aims to contribute to the research on the transformation of political concepts using a case study of transition. This political concept is examined within the period of the so-called historical rupture of 1989/91 in the then Socialist Republic of Croatia, that is, the Republic of Croatia. Setting up a methodological framework based on the work of Michael Freeden and Reinhart Koselleck, the paper attempts to answer the questions regarding the transformation of the political concept of transition, its constituent elements, how they relate to each other and how they reflected the reality of that time. The paper is based on the analysis of the weekly Danas and the monthly journal Banka, along with various other scientific articles, interviews and books. It suggests that by the very development of the political concept of transition at the time, the actors contributed to the context of restoration of capitalism. In the process, these actors divided reality into two main spheres, political and economic, and placed their own perspectives within each of these spheres. In the political sphere, they aspired to democratisation and pluralism of political parties, while in the economic sphere their aspirations were private ownership and greater economic efficiency. As a consequence, the radical changes of that time (historical fracture) were formulated through the political concept of transition, which today largely defines our conception of the recent past.

Key words: political transition, economic transition, capitalism, Croatia 